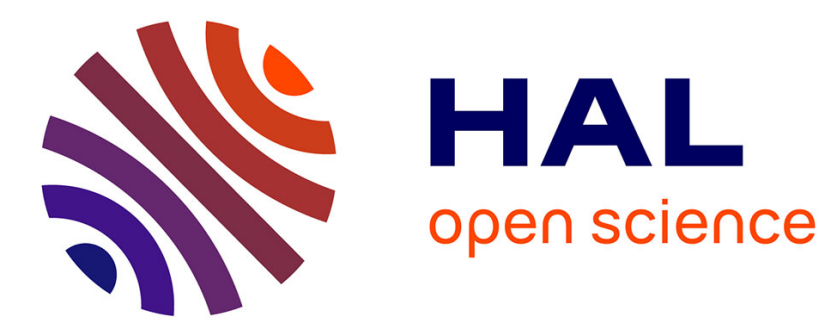

\title{
Carbon nanotubes in novel ceramic matrix nanocomposites
}

Alain Peigney, Christophe Laurent, Emmanuel Flahaut, Abel Rousset

\section{To cite this version:}

Alain Peigney, Christophe Laurent, Emmanuel Flahaut, Abel Rousset. Carbon nanotubes in novel ceramic matrix nanocomposites. Ceramics International, 2000, vol. 26, pp. 677-683. 10.1016/S02728842(00)00004-3 . hal-00957547

\section{HAL Id: hal-00957547 https://hal.science/hal-00957547}

Submitted on 10 Mar 2014

HAL is a multi-disciplinary open access archive for the deposit and dissemination of scientific research documents, whether they are published or not. The documents may come from teaching and research institutions in France or abroad, or from public or private research centers.
L'archive ouverte pluridisciplinaire HAL, est destinée au dépôt et à la diffusion de documents scientifiques de niveau recherche, publiés ou non, émanant des établissements d'enseignement et de recherche français ou étrangers, des laboratoires publics ou privés. 


\section{OATAO \\ Open Archive Toulouse Archive Ouverte}

\section{Open Archive TOULOUSE Archive Ouverte (OATAO)}

OATAO is an open access repository that collects the work of Toulouse researchers and makes it freely available over the web where possible.

This is an author-deposited version published in : http://oatao.univ-toulouse.fr/ Eprints ID : 10979

To link to this article : DOI:10.1016/S0272-8842(00)00004-3

URL : http://dx.doi.org/10.1016/S0272-8842(00)00004-3

\section{To cite this version :}

Peigney, Alain and Laurent, Christophe and Flahaut, Emmanuel and Rousset, Abel Carbon nanotubes in novel ceramic matrix

nanocomposites. (2000) Ceramics International, vol. 26 ( $\left.{ }^{\circ} 6\right)$. pp.

677-683. ISSN 0272-8842

Any correspondance concerning this service should be sent to the repository administrator: staff-oatao@listes-diff.inp-toulouse.fr 


\title{
Carbon nanotubes in novel ceramic matrix nanocomposites
}

\author{
A. Peigney*, Ch. Laurent, E. Flahaut, A. Rousset \\ Laboratoire de Chimie des Matériaux Inorganiques, ESA CNRS 5070, Université Paul-Sabatier, F 31062 Toulouse cedex 4, France
}

\begin{abstract}
Novel carbon nanotubes-metal-ceramic nanocomposite powders and dense materials have been prepared and their microstructure and mechanical properties have been investigated. After a brief review on the structure, synthesis and physical properties of carbon nanotubes, we describe an original catalytic method that produces ceramic-matrix composite powders that contain in situ grown nanotubes. The synthesis parameters that favour the obtention of very high quantities of nanotubes are discussed. The quality of the nanotubes is also addressed. The microstructure and mechanical properties of the materials prepared by hot-pressing of these powders are presented. The influence of carbon nanotubes in such composites is discussed in view of potential applications.
\end{abstract}

Keywords: B. Nanocomposites; C. Mechanical properties

\section{Introduction}

Although hollow carbon fibres have been observed for several decades, it is the report by Iijima [1] in 1991 on the obtention of carbon tubes with a diameter in the nanometer range, the so-called carbon nanotubes (CNTs), and on their relations to the recently discovered fullerenes, that triggered a world wide research effort devoted to improve their synthesis, to determine their structure and to calculate and measure their physical properties. Indeed, theoretical as well as experimental studies point out that the carbon nanotube is a material with extraordinary strength [2]. Consequently, CNTs emerge as potentially attractive materials as reinforcing elements in composites, particularly in ceramic-matrix composites.

Many methods are used to produce $\mathrm{CNT}_{\mathrm{s}}$ : arc-discharge in the absence or presence of metal, laser-vaporization of a metal-graphite composite target, carbon monoxide disproportionation or catalytic decomposition of hydrocarbons on small catalytic metal particles $(\mathrm{Fe}, \mathrm{Co}, \mathrm{Ni}$, $\mathrm{Cu}$ ) [3]. Purification is generally required because multiple forms of carbon are produced besides $\mathrm{CNT}_{\mathrm{s}}$. Moreover, to achieve a CNTs-ceramic composite from as-prepared CNTs, it would be necessary to disperse homogeneously CNTs in a ceramic powder.

* Corresponding author. Tel.: + 33 (0) 5-61-55-61-75; fax: + 33 (0) 561-55-61-63.

E-mail address: peigney@iris.ups-tlse.fr (A. Peigney).
We have proposed a novel catalysis method for the in situ production, in a composite powder, of a huge amount of CNTs, which cover all the matrix grains similarly to a web [4]. After a brief review on the structure, synthesis and physical properties of carbon nanotubes we hereafter, describe this method and discuss the synthesis parameters that favour the obtention of very high quantities of nanotubes with as few other forms of carbon as possible in CNTs-metal-ceramic nanocomposite powders (metal: $\mathrm{Fe}, \mathrm{Co}, \mathrm{Ni}$ and their alloys; ceramic: $\mathrm{Al}_{2} \mathrm{O}_{3}, \mathrm{MgAl}_{2} \mathrm{O}_{4}$ and $\mathrm{MgO}$ ). The microstructure and properties of the materials prepared by hot-pressing the CNTs- $\mathrm{Fe}-\mathrm{Al}_{2} \mathrm{O}_{3}$ powders is also presented.

\section{Carbon nanotubes (CNTs)}

\subsection{Structure}

A comprehensive description of the structure, properties and applications of carbon nanotubes is given in the book by Dresselhaus et al. [3], to which the reader is referred for more details. The structure of a single wall carbon nanotube (SWNT) is described by rolling one graphene sheet to form a hollow tube (Fig. 1) which is closed at the two tips by half fullerenes or more complex structures including pentagons.

When the axis of the CNTs is normal to a threefold or fivefold axis of the half-fullerene, this structure is called 


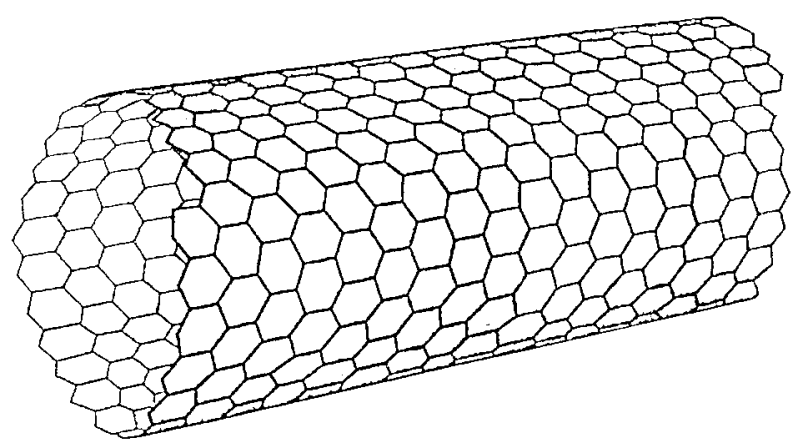

Fig. 1. A part of a zigzag single wall carbon nanotube (SWNT).

zigzag (Fig. 1) or armchair respectively. Besides these two simples structures, more complex ones, which present helicity, are called chiral structures. The smallest inner diameter achieved is that of the fullerene $\mathrm{C}_{60}$ (about $0.7 \mathrm{~nm}$ ) and lengths often reach several micrometers and sometimes some tens of micrometers, giving very high aspect ratios $(1000-10,000)$.

Multiwalled nanotubes (MWNTs) are composed of concentricaly rolled graphene sheets. The measured interlayer distance $(0.34 \mathrm{~nm})$ is very close to that measured between graphene sheets in graphite and no particular correlation appears between the chirality of concentric layers. Very often, SWNTs or MWNTs are found together in bundles where the intertube interaction may be strong.

\subsection{Properties}

Theoretical and experimental studies have shown that CNTs have excellent mechanical properties: the Young's modulus of MWNTs has been calculated to be up to 1.4 times that of a graphite whiskers [5] and values derived from thermal vibrations experiments performed on several MWNTs in a transmission electron microscope [6] are in the 0.4-3.7 $\mathrm{TPa}$ range. Moreover, the CNTs are extraordinarily flexible under large strains and resist failure under repeated bending [2].

Both theoretical and experimental works on electronic properties have shown a metallic or semi-conducting behaviour of the SWNTs and MWNTs. Scanning tunneling microscopy and spectroscopy have recently evidenced that these properties do indeed depend on diameter and helicity [7].

\subsection{Synthesis methods}

A first way to produce CNTs is the arc-discharge between carbon electrodes in inert gas atmospheres, using $\mathrm{Fe}$ or $\mathrm{Co}$ as catalysts to increase both the quantity and length of the tubes and to favour the formation of SWNTs [8]. However, the so-obtained product is a mixture of CNTs and amorphous carbon, nanoparticles and other forms of carbons. A purification has to be conducted but it decreases the yield to about $2 \%$. A second way, is an adapted laser-ablation of transition metal/graphite composite rods which produces "ropes" of SWNTs [9].

The most promising way, in terms of great quantities and low cost is probably the catalytic decomposition of hydrocarbons on small metal particles $(\mathrm{Fe}, \mathrm{Co}, \mathrm{Ni}, \mathrm{Cu}$, $\mathrm{Mo}, \mathrm{Pt}$ ) which leads to autentic CNTs when the catalytic particles are sufficiently small $(<20 \mathrm{~nm})$. Because the minimal tube internal diameter that can be obtained is that of the catalytic particle, the main difficulty is to obtain nanometer sized active metal particles at the temperature of the catalytic decomposition of hydrocarbons $\left(\geqslant 800^{\circ} \mathrm{C}\right)$. Using a zeolite-supported Co catalyst, Hernadi et al. [10] reported carbon tubes only $4 \mathrm{~nm}$ in diameter as well as $60 \mu \mathrm{m}$ long tubes, but they point out that the longest tubes are also the thickest.

The present authors have proposed an original catalytic method aiming at obtaining metal particles at the size required for Iijima's-type CNTs. By selective reduction in a $\mathrm{H}_{2}-\mathrm{CH}_{4}$ gas mixture of an $\mathrm{Al}_{2-2 x} \mathrm{Fe}_{x} \mathrm{O}_{3}$ solid solution, the pristine Fe nanoparticles formed insitu upon reduction of the very homogeneously dispersed surface $\mathrm{Fe}^{3+}$ ions are active at a size adequate for the catalytic formation of nanotubes [4]. The resulting CNTs- $\mathrm{Fe}-\mathrm{Al}_{2} \mathrm{O}_{3}$ composite powder contains a huge amount of SWNTs and MWNTs with a diameter in the 1.5-15 nm range (Fig. 2). Most MWNT appear to have only 2 or 3 walls. The nanotubes are arranged in bundles smaller than $100 \mathrm{~nm}$ in diameter and that may be up to $100 \mu \mathrm{m}$ long. It has been calculated that the total bundle length in $1 \mathrm{~g}$ of composite powder is equal to more than $100,000 \mathrm{~km}$. We have shown that to obtain carbon essentially in the form of nanotubes in the composite powders, it is necessary to operate from the stable $\alpha$-solid solution rather than from amorphous or $\eta$; solid solutions [11], and it is preferable to reduce the monophase oxide solid solutions (cat\% $\mathrm{Fe} \leqslant 10$ ) rather than mixtures [12] of $\mathrm{Al}_{2} \mathrm{O}_{3}$-rich and $\mathrm{Fe}_{2} \mathrm{O}_{3}$-rich solid solutions.

\section{CNTs-Metal-ceramic nanocomposite powders}

\subsection{Experimental methods}

We have prepared solid solutions based on $\alpha-\mathrm{Al}_{2} \mathrm{O}_{3}$, $\mathrm{MgAl}_{2} \mathrm{O}_{4}$ and $\mathrm{MgO}$ substituting $\mathrm{Al}^{3+}$ and $\mathrm{Mg}^{2+}$ ions by $\mathrm{Fe}^{3+}$ ions and $\mathrm{Fe}^{2+}, \mathrm{Co}^{2+}$ or $\mathrm{Ni}^{2+}$ ions respectively, by the methods described elsewhere [13,14]. The oxide solid solutions were reduced in a $\mathrm{H}_{2}-\mathrm{CH}_{4}$ atmosphere at various temperatures $\left(T_{\mathrm{r}}\right)$ using different $\mathrm{CH}_{4}$ contents and during different times $\left(t_{\mathrm{r}}\right)$, as required for the study. The so-obtained composite powders have been characterized by a variety of techniques including XRD, SEM, TEM and HREM. 
The specific surface area of the powders, measured by the BET method (using $\mathrm{N}_{2}$ adsorption at liquid $\mathrm{N}_{2}$ temperature), are labelled $\mathrm{S}_{\mathrm{o}}$ for the oxide solid solution, $S_{n}$ for the nanocomposite powder obtained after reduction and $S_{\text {on }}$ for the oxidized nanocomposite powder obtained after a reoxidation treatment in air at $900^{\circ} \mathrm{C}$ which eliminates all carbon. As proposed elsewhere [4,11,12], the difference $\Delta S=S_{\mathrm{n}}-S_{\text {on }}$ essentially represents the quantity of nanotube bundles in the composite powder. The carbon content $\left(C_{\mathrm{n}}\right)$ in the reduced powder was determined by flash combustion. The ratio $\Delta S / C_{\mathrm{n}}$, can be considered as representing the quality of the nanotubes, a higher figure for $\Delta S / C_{\mathrm{n}}$ denoting a smaller average tube diameter and/or more carbon in tubular form $[4,11,12]$, which we consider a better quality of carbon.

\subsection{Results and discussion}

Generally, the reduced powder is so densely agglomerated that it retains the shape of the reduction vessel when transferred in a storage box. As shown on the SEM observations (Fig. 2a), the web of CNTs bundles gives a cohesion to the nanocomposite powder. We have determined that the bundles are always smaller than 100 $\mathrm{nm}$ in diameter, appear to be very flexible, and some have been traced for $100 \mu \mathrm{m}$. For given $T_{\mathrm{r}}$ and $t_{\mathrm{r}}$, the increase in the $\mathrm{CH}_{4}$ ratio in the $\mathrm{H}_{2-}-\mathrm{CH}_{4}$ mixture increases the quantity of nanotubes but is detrimental to their quality. Indeed, more CNTs bundles appear on SEM images for $30 \% \mathrm{CH}_{4}$ (Fig. 2c) than for $12 \% \mathrm{CH}_{4}$ (Fig. 2b), but numerous large, short filaments, also appear in the first sample. Milling the starting solid solution by the attrition method allows the synthesis of powders in which the relative dispersion of CNTs bundles and matrix grains is considerably enhanced (Fig. 2d). Both MWNTs and SWNTs, a few nanometers in diameter, are found on HREM images of nanocomposite powders (Fig. 3a,b). The CNTs are free of deposits of amorphous carbon when the quality parameter is high $\left(\Delta S / C_{n} \geqslant 200 \mathrm{~m}^{2} / \mathrm{g}\right)$. Most MWNTs appear to have only 2 or 3 walls. XRD analyses conducted on CNTs- $-\mathrm{FeAl}_{2} \mathrm{O}_{3}$ powders always show the presence of $\alpha$ $\mathrm{Fe}$, but sometimes also of $\mathrm{Fe}_{3} \mathrm{C}$ or $\mathrm{Fe}_{5} \mathrm{C}_{2}$.

Increasing the reduction temperature $T_{\mathrm{r}}$ (Fig. 4a,b) enhances the carbon content in the nanocomposite powder $\left(C_{\mathrm{n}}\right)$ and favours the quantity of nanotubes
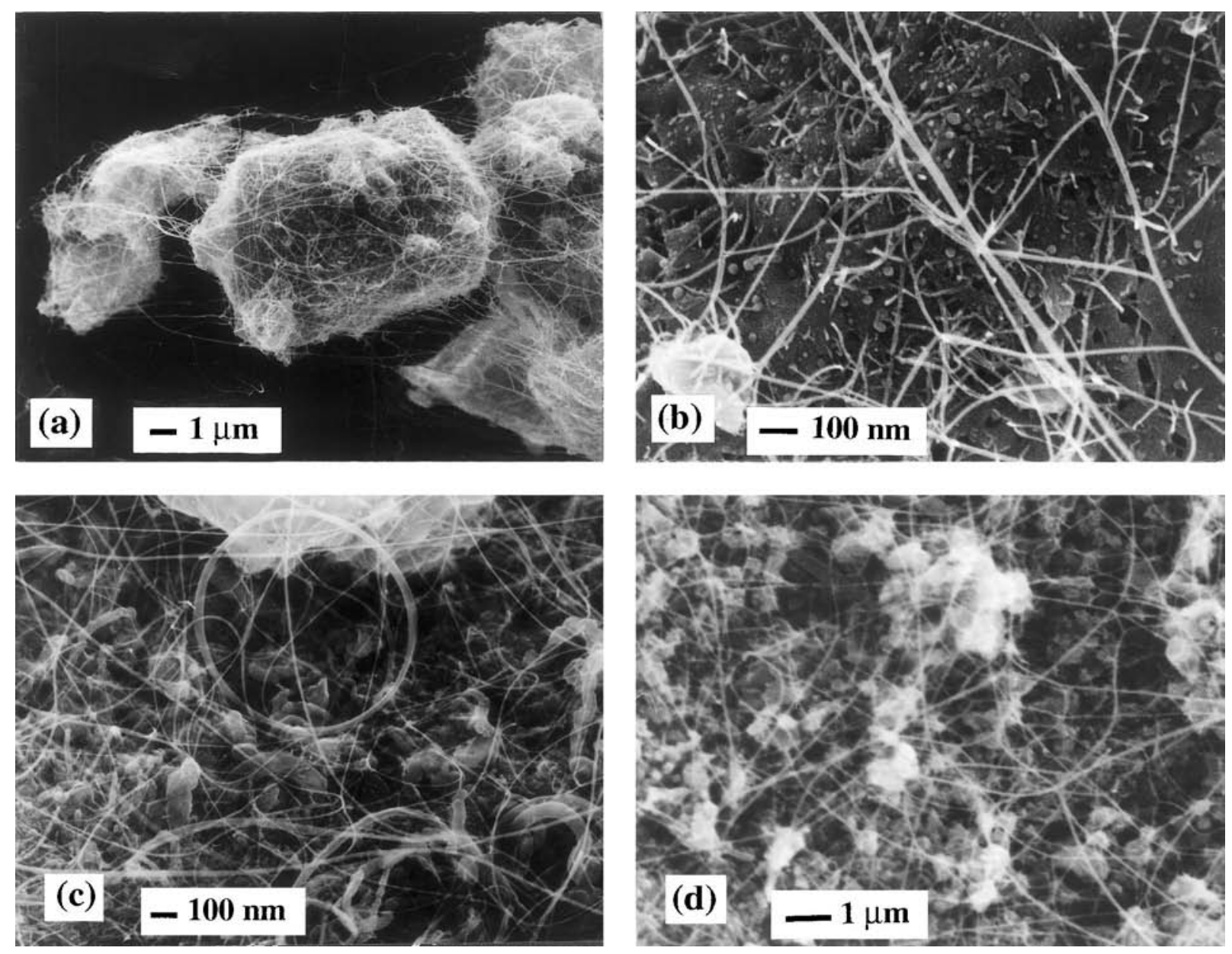

Fig. 2. SEM images of some nanocomposite powders: (a) $5 \mathrm{wt} \% \mathrm{Fe}, 30 \% \mathrm{CH}_{4}, T_{\mathrm{r}}=1050^{\circ} \mathrm{C}, t_{\mathrm{r}}=1 \mathrm{~h} ;$ (b) $10 \mathrm{wt} \% \mathrm{Fe}, 12 \% \mathrm{CH}_{4}, T_{\mathrm{r}}=1070{ }^{\circ} \mathrm{C}, t_{\mathrm{r}}=$ $6 \mathrm{~min}$; (c) $10 \mathrm{wt} \% \mathrm{Fe}, 30 \% \mathrm{CH}_{4}, T_{\mathrm{r}}=1070^{\circ} \mathrm{C}, t_{\mathrm{r}}=6 \mathrm{~min}$; (d) attritor-milled solid solution, $10 \mathrm{wt} \% \mathrm{Fe}, 12 \% \mathrm{CH}_{4}, T_{\mathrm{r}}=1050^{\circ} \mathrm{C}, t_{\mathrm{r}}=1 \mathrm{~h}$. 

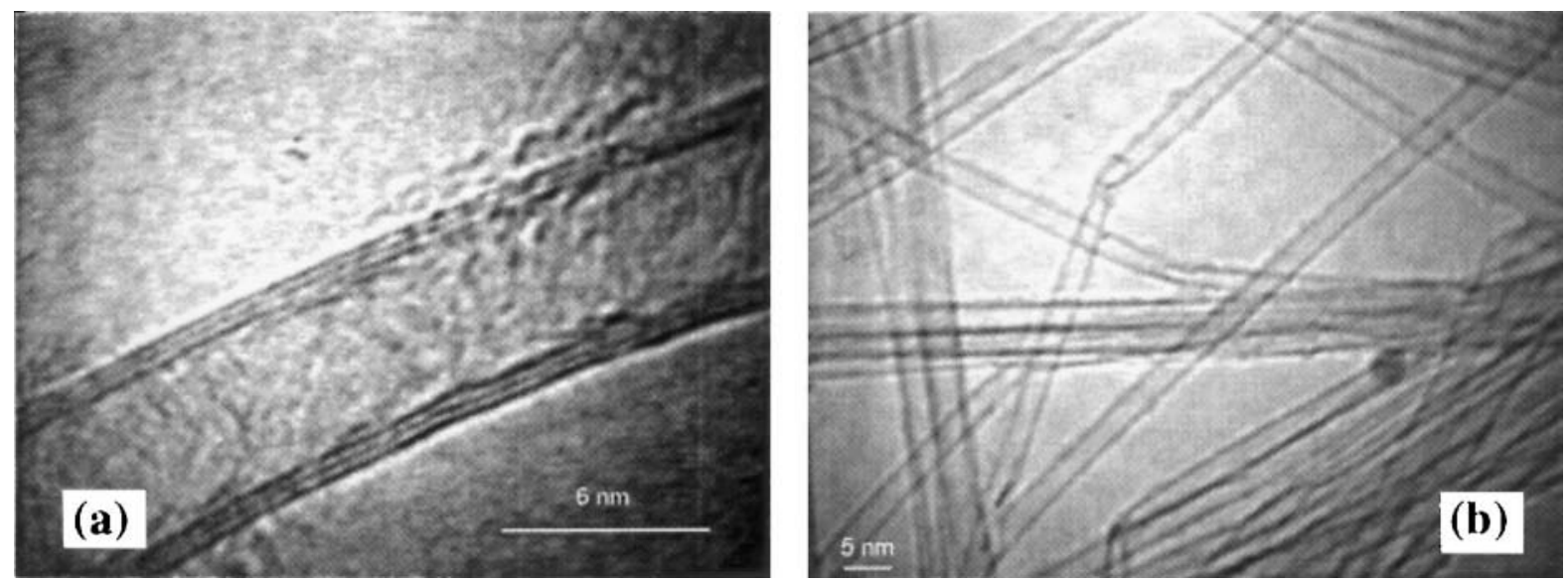

Fig. 3. HREM images of nanotubes present in the nanocomposite powders: (a) a 3 walls carbon nanotube; (b) numerous SWNTs having similar diameters (about $3 \mathrm{~nm}$ ).
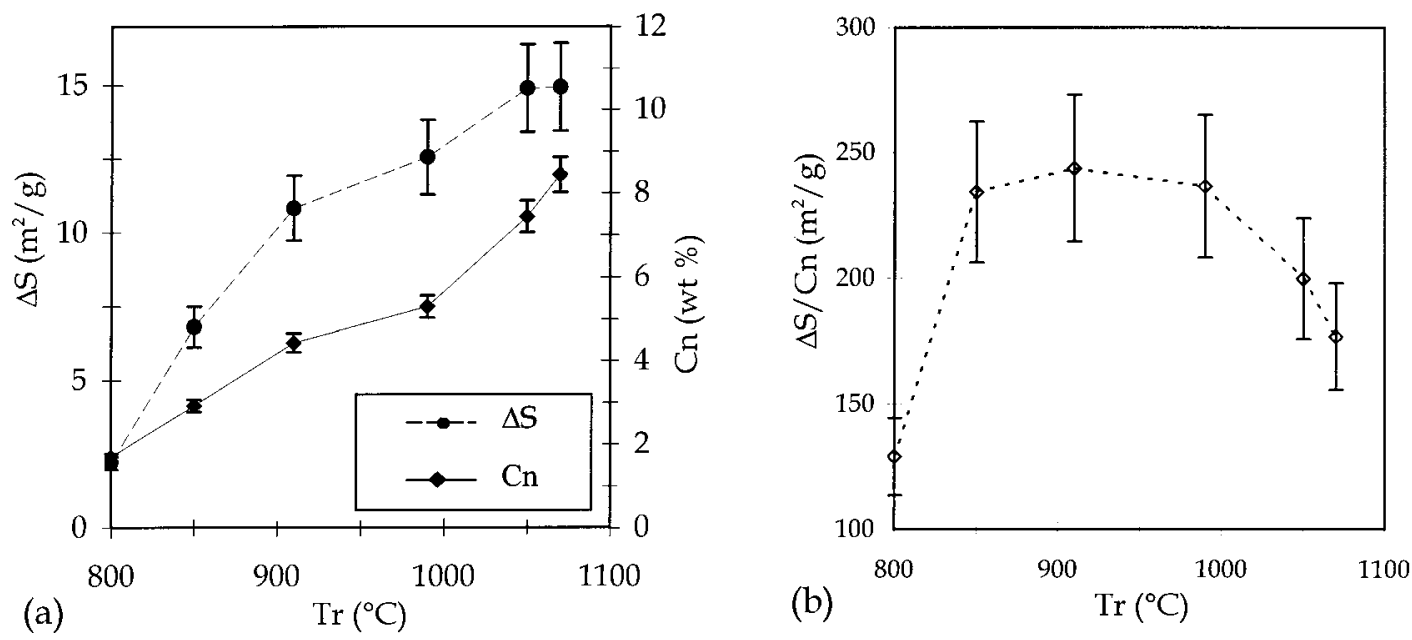

Fig. 4. (a): The carbon content $\left(C_{\mathrm{n}}\right)$ and $\Delta S=S_{\mathrm{n}}-S_{\text {on }}$ versus the reduction temperature. (b): $\Delta S / C_{\mathrm{n}}$ versus the reduction temperature [10 wt $\%$ Fe, $18 \% \mathrm{CH}_{4}, \operatorname{tr}=6$ min. for (a) and (b)].

$(\Delta S)$ because of a higher $\mathrm{CH}_{4}$ supersaturation level in the gas atmosphere, but also provokes a decrease in carbon quality $\left(\Delta S / C_{\mathrm{n}}\right)$. The macroscopic parameters of the powders which present either the greater quantity $\left(\mathrm{A}_{1}\right.$ and $\left.\mathrm{MA}_{1}\right)$ or the better quality $\left(\mathrm{A}_{2}\right.$ and $\left.\mathrm{MA}_{2}\right)$, obtained with optimized synthesis conditions, are reported in Table 1. For CNTs- $\mathrm{Fe}-\mathrm{Al}_{2} \mathrm{O}_{3}$ powders, the best results are obtained with $10 \mathrm{wt} \% \mathrm{Fe}, T_{\mathrm{r}}=1050^{\circ} \mathrm{C}$ and a very short dwell time (6 $\mathrm{min})$, the greater quantity $\left(\Delta S=24.6 \mathrm{~m}^{2} / \mathrm{g}\right)$ and the better quality $\left(\Delta S / C_{\mathrm{n}}=585\right.$ $\left.\mathrm{m}^{2} / \mathrm{g}\right)$ being obtained with a large $(30 \%)$ and a very small $(3 \%)$ proportion of $\mathrm{CH}_{4}$ respectively. We have calculated that a specific surface area of $585 \mathrm{~m}^{2} / \mathrm{g}$ corresponds to MWNTs made of 2 or 3 walls which is in good agreement with HREM observations. For reinforcement applications, we infer that a good compromise is found with $\mathrm{A}_{3}$, prepared using $18 \% \mathrm{CH}_{4}$. This powder contains a huge quantity of CNTs bundles : $\Delta \mathrm{S}$ represents more than $300000 \mathrm{~km}$ of bundles in a gramme of powder [4].
For CNTs-M- $\mathrm{MgAl}_{2} \mathrm{O}_{4}$ nanocomposite powders (M: $\mathrm{Fe}, \mathrm{Co}, \mathrm{Ni}$ and their alloys), prepared in the same conditions than $\mathrm{A}_{3}$, the quantity and quality parameters depend on the nature of the catalyst [16,17]. Indeed, 7.7 $\mathrm{wt} \%$ of the $\mathrm{Fe} / \mathrm{Co}$ alloy and $4 \mathrm{wt} \%$ Co give the best results with respect to the quantity $\left(\Delta S=19.8 \mathrm{~m}^{2} / \mathrm{g}\right)$ and quality $\left(\Delta S / C_{\mathrm{n}}=354 \mathrm{~m}^{2} / \mathrm{g}\right)$ respectivelly $[16,17]$. A novel CNTs-Co-MgO powder has been prepared showing that the synthesis method is effective in the case of MgO-matrix composites, but the conditions have yet to be optimized.

\section{Hot-pressed $\mathrm{CNTs}-\mathrm{Fe}-\mathrm{Al}_{2} \mathrm{O}_{3}$ nanocomposites}

\subsection{Experimental methods}

The powders were hot-pressed in graphite dies at $1475^{\circ} \mathrm{C}$ in a primary vacuum. Massive specimens, in the form of pellets $20 \mathrm{~mm}$ in diameter and $2 \mathrm{~mm}$ thick, were 
polished to a finish better than $6 \mu \mathrm{m}$ with diamond grids. The densities were calculated from the mass and dimensions of the so-obtained pellets. Scanning electron microscopy (SEM) observations of the surface and fracture of some specimen were carried out. We also measured the mechanical characteristics of some composites. The fracture strength $\left(\sigma_{\mathrm{f}}\right)$ was measured by the three-point-bending test on parallelipipedic specimens $(1.8 \times 1.8 \times 16 \mathrm{~mm})$ machined with a diamond saw. The fracture toughness $\left(K_{\mathrm{Ic}}\right)$ was measured by the singleedge-notch-beam (SENB) method, on similar specimens notched using a diamond blade $0.3 \mathrm{~mm}$ in width. The calibration factor proposed by Brown and Srawley [15] was used to calculate the SENB toughness from the experimental results. Cross-head speed was fixed at 0.1 $\mathrm{mm} / \mathrm{min}$.

\subsection{Results and discussion}

From the densities of massive specimen (Table 2), taking into account the densities and the proportions of the different carbon species, we have calculated that the relative densities are in the $91-100 \%$ range. Previous works $[13,14]$ have shown that the hybridization of microcomposites and nanocomposites could result in a further improvement in both the fracture strength and fracture toughness. The mechanical properties obtained on $\mathrm{CNTs}-\mathrm{Fe}-\mathrm{Al}_{2} \mathrm{O}_{3}$ nanocomposites (some being reported in Table 2) show that the additive effect that was expected from the addition of very long carbon nanotubes bundles is not observed. Indeed, if the fracture strength of some composites is higher than that of $\mathrm{Al}_{2} \mathrm{O}_{3}$, it remains lower than those of the carbon free $\mathrm{Fe}-\mathrm{Al}_{2} \mathrm{O}_{3}$ nanocomposites [13] Similar observations are made for the fracture toughness values. No correlation was found between the mechanical properties and the quantity or quality parameters. Moreover, specimen E, prepared with a composite powder issued from an attritor-milled solid solution, has even poorer mechanical properties than the other specimens.

SEM images of fractures (Fig. 5) show that the CNTs bundles remain present in the hot-pressed aluminamatrix composites, but in a smaller quantity than in the starting powder. In specimen E (Fig. 5a,b), the bundles are very homogeneously dispersed between the submicrometric sized alumina grains and the cohesion between the CNTs bundles and the matrix appears to be rather poor. Some CNTs bundles are tight, others are relaxed (Fig. 5a) and the CNTs which compose the bundles are resolved (Fig. 5b). On the surface fracture of $\mathrm{C}_{2}$ (Fig. 5c) some bundles, which seem to have been entrapped in the matrix grains during hot-pressing, are cut near the grain surface, suggesting some degree of bundle pull-out. On the same image, it can be seen that the bundles have been constrained and are bent without being broken. The fracture are intergranular for specimen $\mathrm{E}$ and mostly mixed intergranular-transgranular for the other specimens. We have also determined that

Table 1

Parameters of the nanocomposites powders which contains the greatest quantity of noanotubes $\left(\mathrm{A}_{1}\right.$ and $\left.\mathrm{MA}_{1}\right)$, which contains nanotubes of the

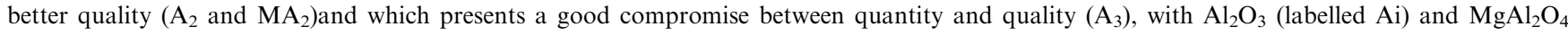
(labelled MAi) matrices. The parameters of a novel CNTs-Co-MgO nanocomposites powder are also mentiones

\begin{tabular}{|c|c|c|c|c|c|c|c|}
\hline Code & Wt $\%$ metal & Matrix & $C_{\mathrm{n}}(\mathrm{wt} \%)$ & $S_{\mathrm{n}}\left(\mathrm{m}^{2} / \mathrm{g}\right)$ & $S_{\text {on }}\left(\mathrm{m}^{2} / \mathrm{g}\right)$ & $\Delta \mathrm{S}\left(\mathrm{m}^{2} / \mathrm{g}\right)$ & $\Delta \mathrm{S} / C_{\mathrm{n}}\left(\mathrm{m}^{2} / \mathrm{g}\right)$ \\
\hline $\mathrm{A}_{1}$ & $10 \% \mathrm{Fe}$ & $\mathrm{Al}_{2} \mathrm{O}_{3}$ & 13.0 & 32.5 & 7.9 & 24.6 & 189 \\
\hline $\mathrm{A}_{2}$ & $10 \% \mathrm{Fe}$ & $\mathrm{Al}_{2} \mathrm{O}_{3}$ & 0.65 & 10.7 & 6.9 & 3.8 & 585 \\
\hline $\mathrm{A}_{3}$ & $10 \% \mathrm{Fe}$ & $\mathrm{Al}_{2} \mathrm{O}_{3}$ & 7.7 & 26.4 & 6.8 & 19.6 & 255 \\
\hline $\mathrm{MA}_{1}$ & $7.7 \% \mathrm{Fe} / \mathrm{Co}$ & $\mathrm{MgAl}_{2} \mathrm{O}_{4}$ & 7.0 & 31.6 & 11.8 & 19.8 & 283 \\
\hline $\mathrm{MA}_{2}$ & $4 \% \mathrm{Co}$ & $\mathrm{MgAl}_{2} \mathrm{O}_{4}$ & 2.6 & 19.2 & 10 & 9.2 & 354 \\
\hline M & $13.5 \% \mathrm{Co}$ & $\mathrm{MgO}$ & 14.5 & 25.3 & 6.6 & 18.7 & 129 \\
\hline
\end{tabular}

Table 2

Some characteristics of the powders, density and mechanical properties of the massive (hot-pressed) composites. For E, the oxide solid solution was attritor-milled before the reduction treatment. Some data on $\alpha-\mathrm{Al}_{2} \mathrm{O}_{3}$ and 5 and $10 \mathrm{wt} \% \mathrm{Fe}-\mathrm{Al}_{2} \mathrm{O}_{3}$ nanocomposites (from Ref. 13) are shown for the sake of comparison

\begin{tabular}{|c|c|c|c|c|c|c|c|}
\hline Code & $\mathrm{wt} \% \mathrm{Fe}$ & $\mathrm{Cn}(\mathrm{wt} \%)$ & $\Delta S\left(\mathrm{~m}^{2} / \mathrm{g}\right)$ & $\Delta S / C \mathrm{n}\left(\mathrm{m}^{2} / \mathrm{g}\right)$ & $d_{\mathrm{s}}\left(\mathrm{g} / \mathrm{cm}^{3}\right)$ & $\sigma_{\mathrm{f}}(\mathrm{MPa})$ & $K_{\mathrm{Ic}}\left(\mathrm{MPam}^{1 / 2}\right)$ \\
\hline $\mathrm{C}_{1}$ & 5 & 3.65 & 3.7 & 101 & 3.60 & 470 & 4.8 \\
\hline $\mathrm{C}_{2}$ & 5 & 6.71 & 6.3 & 94 & 3.78 & 471 & 2.8 \\
\hline $\mathrm{D}$ & 10 & 1.64 & 2.6 & 155 & 4.01 & 541 & 3.6 \\
\hline $\mathrm{E}$ & 10 & 5.79 & 10.1 & 174 & 3.84 & 295 & 2.7 \\
\hline \multirow{3}{*}{$\mathrm{Al}_{2} \mathrm{O}_{3}$} & 0 & - & - & - & 3.89 & 330 & 4.4 \\
\hline & 5 & - & - & - & 4.01 & 600 & 7.5 \\
\hline & 10 & - & - & - & 4.06 & 630 & 7.2 \\
\hline
\end{tabular}



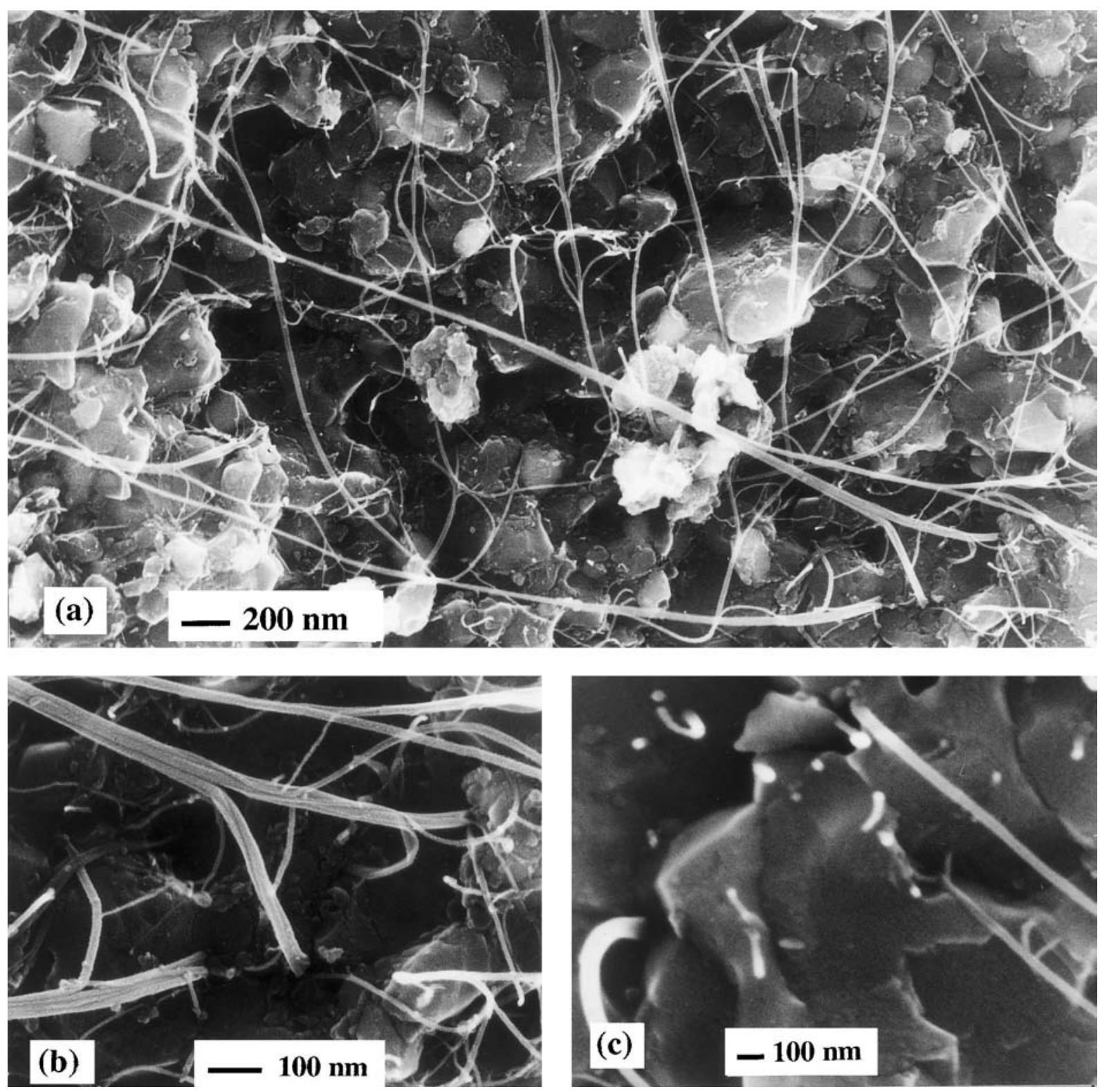

Fig. 5. Scanning electron micrographs of the fractures of some composites: $(\mathrm{a}, \mathrm{b})$ specimen $\mathrm{E}$; (c) specimen $\mathrm{C}_{2}$.

the intergranular Fe particles are smaller in CNTs- $\mathrm{Fe}-$ $\mathrm{Al}_{2} \mathrm{O}_{3}$ than in $\mathrm{Fe}-\mathrm{Al}_{2} \mathrm{O}_{3}$ nanocomposites probably because the graphene sheets which wrap up these particles in the powders inhibit some diffusion processes during hot-pressing.

In the absence of CNTs [13], the fractures are essentially transgranular because the intragranular metal nanometric particles promote such a fracture, even for a matrix with a micrometric grain size. Thus, in CNTs$\mathrm{Fe}-\mathrm{Al}_{2} \mathrm{O}_{3}$ composites, the reinforcement mechanisms involving the intragranular metal particles would be far less operative. However, some of the SEM observations seem to indicate that the nanotubes bundles could dissipate some fracture energy, particularly for composites with micrometric matrix grains. The residual porosity may impair the mechanical resistance and a partial annihilation of the different reinforcement mechanisms may operate. Possibly the nanotube volume fraction should be greatly increased : we have calculated that the CNTs volume fraction is about $20 \%$ in the powder but it probably decreases notably during the hot pressing. We presently work to increase the CNTs volume fraction in the composite powders and to optimize the hot pressing treatment with the aim to increase the relative density and to preserve the CNTs from degradation during this process. Moreover, the hot pressing of CNTs- $\mathrm{M}-\mathrm{MgAl}_{2} \mathrm{O}_{4}$ and CNTs-M-MgO (M: Fe, Co, $\mathrm{Ni}$ and their alloys) nanocomposites is in progress to evaluate the influence of the nature of the ceramic matrix and metal particles on the microstructure and 
mechanical properties. Possibly, CNTs bundles should be aligned to contribute to the reinforcement.

\section{Conclusions}

Several experimental works have recently confirmed the theorically predicted outstanding mechanical properties of carbon nanotubes (CNTs). Consequently, CNTs emerge as potentially attractive materials as reinforcing elements in ceramic matrix composites.

The first difficulty to achieve a CNTs-ceramic composite from as-prepared CNTs, is to disperse homogeneously the CNTs in a ceramic powder. We have proposed a novel catalysis method for the in-situ production, in a composite powder, of a huge amount of CNTs bundles, which cover all the matrix grains looking like a web. The elaboration conditions of CNTs-Fe$\mathrm{Al}_{2} \mathrm{O}_{3}$ and CNTs- $\mathrm{M}-\mathrm{MgAl}_{2} \mathrm{O}_{4}$ (M: $\mathrm{Fe}, \mathrm{Co}, \mathrm{Ni}$ and their alloys) nanocomposite powders have been optimized with the aim to obtain both a great quantity of CNTs (up to $300000 \mathrm{~km}$ of CNTs bundles in a gramme of powder) and a good quality of carbon, i.e. a smaller average tube diameter and/or more carbon in tubular form. Because these two parameters generally vary in opposite directions, a compromise must be found. For reinforcement applications, with $\mathrm{CNTs}-\mathrm{Fe}-\mathrm{Al}_{2} \mathrm{O}_{3}$ powders, we infer that a good compromise is obtained with $18 \% \mathrm{CH}_{4}$ in the $\mathrm{H}_{2}-\mathrm{CH}_{4}$ gas mixture, $10 \mathrm{wt} \% \mathrm{Fe}$ and a reducing thermal treatement performed at $1050^{\circ} \mathrm{C}$ with a short dwell time (6 $\mathrm{min})$.

Massive CNTs- $\mathrm{Fe}-\mathrm{Al}_{2} \mathrm{O}_{3}$ composites have been prepared by hot-pressing. SEM observations show that the CNTs bundles remain present in the composites, but in a smaller quantity than in the starting powder. Although some of the SEM observations seem to indicate that the nanotubes bundles could dissipate some fracture energy, the obtained mechanical properties show that the reinforcement effect that was expected from the addition of very long carbon nanotubes bundles is not observed. The improvement of the composite microstructure, the change in the nature of the matrix and attemps to align the CNTs are works actually in progress.

\section{References}

[1] S. Iijima, Nature 354 (1991) 56.

[2] M.R. Falvo, G.J. Clary, R.M. Taylor II, V. Chi, F.P. Brooks Jr., S. Washburn, R. Superfine, Nature 389 (1997) 582.

[3] M.S. Dresselhaus, G. Dresselhaus, P.C. Eklund, Science of fullerenes and carbon nanotubes, Academic Press, San Diego.

[4] A. Peigney, Ch. Laurent, A. Dobigeon, A. Rousset, J. Mater. Res. 12 (1997) 613.

[5] S.B. Sinnott, C.T. White, D.W. Brenner, Mat. Res. Soc. Symp. Proc 359 (1995) 241.

[6] M.M.J. Treacy, T.W. Ebbesen, J.M. Gibson, Nature 381 (1996) 678.

[7] W.G. Wildoer, L.C. Venema, A.G. Rinzler, R.E. Smalley, C. Dekker, Nature 391 (1998) 59.

[8] S. Iijima, T. Ichihashi, Nature 363 (1993) 603.

[9] T. Guo, P. Nikolaev, A. Thess, D.T. Colbert, R.E. Smalley, Chem. Phys. Lett. 243 (1995) 49.

[10] K. Hernadi, A. Fonseca, J.B. Nagy, D. Bernaerts, A. Fudala, A.A. Lucas, Zeolites 17 (1996) 416.

[11] Ch. Laurent, A. Peigney, A. Rousset, J. Mater. Chem. 8 (5) (1998) 1263.

[12] Ch. Laurent, A. Peigney, O. Dumortier, A. Rousset, J. Eur. Ceram. Soc. 18 (1998) 1995.

[13] X. Devaux, Ch. Laurent, M. Brieu, A. Rousset, in: Composites Materials, eds A. T. Di Benedetto, L. Nicolais, R. Watanabe, Elsevier Science Publishers, Amsterdam, Netherlands, 1992.

[14] O. Quenard, Ch. Laurent, M. Brieu, A. Rousset, NanoStruct. Mater. 7 (1996) 497.

[15] W.F. Brown, J.E. Srawley, ASTM Spec. Tech. Pub., 410, ASTM, Philadelphia, PA, USA, 1966.

[16] A. Govindaraj, E. Flahaut, Ch. Laurent, A. Peigney, A. Rousset, C.N.R. Rao, J. Mater. Res. 14 (6) (1999) 2567.

[17] E. Flahaut, A. Govindaraj, A. Peigney, Ch. Laurent, A. Rousset, C.N.R. Rao, Chem. Phys. Let. 300 (1999) 236. 